\title{
Article \\ Fertigation Strategies to Alleviate Fertilizer Contamination Generated by Tomato Crops under Plastic Greenhouses
}

\author{
Blanca María Plaza, María Teresa Lao (D) and Silvia Jiménez-Becker *(D) \\ Department of Agronomy, School of Engineering, University of Almería, CIAIMBITAL, Agrifood Campus of \\ International Excellence ceiA3, Ctra. Sacramento s/n, La Cañada de San Urbano, 04120 Almería, Spain; \\ blancamph@yahoo.es (B.M.P.); mtlao@ual.es (M.T.L.) \\ * Correspondence: sbecker@ual.es; Tel.: +34-950-015-952
}

check for updates

Citation: Plaza, B.M.; Lao, M.T.; Jiménez-Becker, S. Fertigation Strategies to Alleviate Fertilizer Contamination Generated by Tomato Crops under Plastic Greenhouses. Agronomy 2021, 11, 444. https:// doi.org/10.3390/agronomy11030444

Academic Editor: Dionisio Andújar

Received: 2 February 2021

Accepted: 24 February 2021

Published: 27 February 2021

Publisher's Note: MDPI stays neutral with regard to jurisdictional claims in published maps and institutional affiliations.

Copyright: (c) 2021 by the authors. Licensee MDPI, Basel, Switzerland. This article is an open access article distributed under the terms and conditions of the Creative Commons Attribution (CC BY) license (https:// creativecommons.org/licenses/by/ $4.0 /)$.

\begin{abstract}
The rapid development of greenhouse horticulture has brought about a dramatic increase in the nitrate pollution of aquifers. The optimization of nitrogen application is an important tool to minimize nitrogen losses. The objective of this research was to assess the effect of different fertigation strategies, based on the reduction of the nitrogen applied and the use of a percentage of $\mathrm{NH}_{4}{ }^{+}$as a nitrogen source, on the decrease in the environmental impact caused by the traditional system, as well as to evaluate if this is compatible with a high fruit yield (considering quantity and quality). Lycopersicum esculentum Mill cv. Forteza plants were grown in a polyethylene greenhouse. Tomato yield and quality were evaluated, along with leachates, which were collected by means of rigid plastic lysimeters. The proposed strategies did not reduce fruit yield. However, the reduction in the nitrate applied caused firmness and ${ }^{\circ}$ Brix decrease, together with a diminution in titratable acidity until 124 days after transplanting. Nevertheless, these effects were not observed with the replacement of some of the $\mathrm{NO}_{3}{ }^{-}$by $\mathrm{NH}_{4}{ }^{+}$. The reduction in fertilizer inputs significantly improved water and nutrient $\left(\mathrm{N}, \mathrm{P}\right.$ and $\mathrm{K}$ ) use efficiency. The treatment with $\mathrm{NH}_{4}{ }^{+}$improved $\mathrm{K}$ use efficiency, compared to the conventional treatment, but $\mathrm{P}$ decreased. The highest $\mathrm{NO}_{3}{ }^{-}$and $\mathrm{K}$ leaching was detected in the traditional treatment.
\end{abstract}

Keywords: nutrient use efficiency; ammonium; nitrogen leaching; yield quantity; quality

\section{Introduction}

Almeria is located in the south-east of Spain $\left(36^{\circ} 50^{\prime} \mathrm{N} 02^{\circ} 23^{\prime} \mathrm{W}\right)$; this province supplies vegetables to Europe throughout the winter season due to intensive greenhouse horticulture production [1]. Almeria boasts a greenhouse land surface of 31,614 ha, and it is the area with the highest concentration of protected crop surface (greenhouses) both in Spain and the world [2]. This province has experienced vast changes over the last 40 years, and it has become one of the most efficient agro-industrial complexes in the world. This rapid growth has generated sustainability problems, such as water pollution, water overuse, or inadequate waste management [3]. This rapid development of greenhouse horticulture has brought about a dramatic increase in the nitrate $\left(\mathrm{NO}_{3}{ }^{-}\right)$pollution of aquifers [1]. Most of the areas where the greenhouses are concentrated have been classified as Nitrate Vulnerable Zones, in accordance with the EU Nitrate Directive and, consequently, producers are required to develop and implement crop management practices to reduce $\mathrm{NO}_{3}{ }^{-}$contamination $[4,5]$.

The use efficiency of the applied nitrogen $(\mathrm{N})$ is estimated, typically, to be $<50 \%$ in most crops. Synthetic $\mathrm{N}$ fertilizer is a relatively low-cost input, resulting in potential excessive application [6]. The overapplication of nutrients and water is common in intensive greenhouse systems [7]. The unused $\mathrm{N}$ fertilizer may remain in the soil or be subject to denitrification, volatilization and leaching to groundwater [8]. Optimizing applications of nutrients and water, and their use efficiencies is, therefore, important to minimize potential losses of nutrients to the environment, particularly $\mathrm{N}$ [6]. The type of $\mathrm{N}$ applied, and 
the timing of fertilizer applications are important to reduce losses due to volatilization and leaching [9]. A study conducted by Wang et al. [7] revealed that this strategy has great potential to reduce nutrient and water use while maintaining the same yield in greenhouse production.

The advantage conferred by the use of ammonium $\left(\mathrm{NH}_{4}^{+}\right)$is related to its fixation and release, and it can play a crucial role in the efficiency of fertilizer $\mathrm{N}$ [10], as it impacts the indigenous soil $\mathrm{N}$ supply towards crop $\mathrm{N}$ uptake. Nitrogen contributions from soil, including defixation of $\mathrm{NH}_{4}{ }^{+}$in a given year/season, can greatly alter the recovery efficiency of the applied $\mathrm{N}$, because a large fertilizer $\mathrm{N}$ substitution of soil $\mathrm{N}$ [11] occurs. In soils with a high $\mathrm{NH}_{4}{ }^{+}$fixation capacity, a part of the $\mathrm{NH}_{4}{ }^{+}$supplied through $\mathrm{NH}_{4}{ }^{+}$-forming or $\mathrm{NH}_{4}{ }^{+}$-containing fertilizers may be bound in clay mineral interlayers. Increasing $\mathrm{NH}_{4}{ }^{+}$ fixation can be a way of building up an available $\mathrm{N}$ pool in soils to optimize crop recovery and minimize $\mathrm{N}$ losses into the environment [12], as the $\mathrm{NH}_{4}{ }^{+}$ions after penetration into the clay mineral interlayers are excluded from nitrification [13] and are thus protected against leaching. The fixed $\mathrm{NH}_{4}{ }^{+}$pool can thus function as a kind of buffer which could influence $\mathrm{N}$ losses from soils and mineral $\mathrm{N}$ availability to crops [11]. Ammonium nitrate and $\mathrm{Ca}\left(\mathrm{NO}_{3}\right)_{2}$ treatments applied to "Penncross" creeping bentgrass, resulted in $\mathrm{NO}_{3}{ }^{-}$leachate concentrations which did not exceed $1.5 \mathrm{mg} \mathrm{L}^{-1}$ [14]. When application levels were $19.52 \mathrm{Kg} \mathrm{N} \mathrm{ha}^{-1}, \mathrm{~N}$ applied lost (\%) was 0.2 , and 0.12 for $\mathrm{Ca}\left(\mathrm{NO}_{3}\right)_{2}$ and $\mathrm{NH}_{4} \mathrm{NO}_{3}$, respectively.

Fertilizers containing $\mathrm{NH}_{4}{ }^{+}$and / or urea could induce soil acidification in fertigated orchards [15]; their acidifying effects result mainly from the generation of hydrogen cations $\left(\mathrm{H}^{+}\right)$resulting from the biological oxidation of $\mathrm{NH}_{4}{ }^{+}$into $\mathrm{NO}_{3}{ }^{-}$ions [16]. Decreased $\mathrm{pH}$ in the rhizosphere may be beneficial for crops in basic soils; it would also alleviate the negative effects of salinity on growth and improve $\mathrm{N}$ and $\mathrm{P}$ uptake efficiency of drip-irrigated crops in salt-affected soils, by increasing the rhizosphere $\mathrm{P}$ availability and reducing the area of root-salt interaction [17]. Additionally, under saline conditions, $\mathrm{N}$ extraction by plants increases because of avoidance of $\mathrm{NO}_{3}{ }^{-} / \mathrm{Cl}^{-}$competition for uptake. On the other hand, higher supplies of $\mathrm{NH}_{4}{ }^{+}$on basic soils $(\mathrm{pH}>8)$ could produce toxicity, because $\mathrm{NH}_{4}{ }^{+}$ is transformed into $\mathrm{NH}_{3}$, which generates plant toxicity [18]. The sources and doses of nitrogen fertilizers can influence tomato quality. Rebouças et al. [19] have verified the effect of nitrogen fertilization on $\mathrm{pH}$, soluble solid content, titratable acidity, and vitamin $\mathrm{C}$ content. These authors suggest that fertilization practices using $\mathrm{NO}_{3}{ }^{-}$and $\mathrm{NH}_{4}{ }^{+}$are recommended in order to improve quality. Assunção et al. [20] found an increase in ${ }^{\circ}$ Brix and the longitudinal diameter of fruits as a function of the $\mathrm{N}$ dose. The objective of this research was the improvement of fertilizer use efficiency in greenhouse areas in the Mediterranean region, through the assessment of the effect of several fertigation strategies based on the reduction of the total nitrogen applied, as well as on the use of a percentage of $\mathrm{NH}_{4}{ }^{+}$as a nitrogen source, on the decrease in the environmental impacts caused by the traditional system, and if they are compatible with a high fruit yield (quantity and quality).

\section{Materials and Methods}

\subsection{Experimental Site}

The trial was conducted in a polyethylene greenhouse located in Almeria (Spain), with a total area of $1700 \mathrm{~m}^{2}$. Lycopersicum esculentum Mill cv. Forteza plants were grown from 20 August to 20 April, in a plantation frame measuring $0.5 \times 1.7 \mathrm{~m}^{2}$.

The soil was a traditional mulched sandy soil, which is quite common in the Mediterranean area; it consisted of two layers: (1) the bottom layer was a $0.3 \mathrm{~m}$ thick clay loam soil, according to US soil taxonomy, and (2) the top layer was $0.1 \mathrm{~m}$ of sand [21].

Drip irrigation was adopted, with one dripper $\left(3 \mathrm{~L} \mathrm{~h}^{-1}\right)$ per plant. Irrigation frequency was controlled by tensiometers. The water characterization is shown in Table 1; it was classified as $\mathrm{C}_{4}-\mathrm{S}_{3}$, following the Riverside classification system. Irrigation frequency was based on Kc [22]. 
Table 1. Chemical composition of the water irrigation and nutrient solutions.

\begin{tabular}{|c|c|c|c|c|c|c|c|c|c|c|c|}
\hline & \multirow{2}{*}{$E C\left(\mathrm{dS} \mathrm{m}^{-1}\right)$} & \multirow{2}{*}{$\mathrm{pH}$} & \multicolumn{9}{|c|}{ Macronutrients $\left(\mathrm{mmol} \mathrm{L}^{-1}\right)$} \\
\hline & & & $\mathrm{NO}_{3}^{-}$ & $\mathrm{NH}_{4}{ }^{+}$ & $\mathrm{H}_{2} \mathrm{PO}_{4}^{-}$ & $\mathrm{SO}_{4}{ }^{2-}$ & $\mathrm{Cl}^{-}$ & $\mathrm{K}^{+}$ & $\mathrm{Ca}^{2+}$ & $\mathrm{Mg}^{2+}$ & $\mathrm{Na}^{+}$ \\
\hline Water & 0.65 & 8.06 & 0.51 & 0.00 & 0.00 & 0.84 & 2.06 & 0.37 & 2.16 & 2.79 & 1.74 \\
\hline NS & 1.87 & 7.50 & 10.44 & 0.30 & 0.65 & 1.36 & 2.54 & 5.37 & 3.02 & 1.79 & 2.03 \\
\hline $\mathrm{NS}_{65 \%}$ & 1.46 & 7.83 & 7.00 & 0.08 & 0.59 & 1.54 & 2.50 & 3.33 & 2.31 & 1.91 & 2.16 \\
\hline $\mathrm{NS}_{\mathrm{NH} 4}{ }^{+}$ & 1.85 & 7.00 & 9.2 & 1.44 & 0.73 & 1.51 & 2.61 & 4.48 & 2.22 & 1.81 & 2.03 \\
\hline
\end{tabular}

The treatments were: (i) conventional fertigation (NS); (ii) $65 \%$ of the fertilizers applied in conventional fertigation $\left(\mathrm{NS}_{65} \%\right)$; and (iii) with $20 \%$ of the total $\mathrm{N}$ applied in conventional fertigation being $\mathrm{NH}_{4}{ }^{+}\left(\mathrm{NS}_{\mathrm{NH} 4}{ }^{+}\right)(n=4)$.

\subsection{Treatment Details}

Three treatments were established: (i) Conventional fertigation, total $\mathrm{N}$ applied $10.74 \mathrm{mmol} \mathrm{L}^{-1}$ (NS); (ii) $65 \%$ of the fertilizers applied in conventional fertigation, total $\mathrm{N}$ applied $7.08 \mathrm{mmol} \mathrm{L}^{-1}\left(\mathrm{NS}_{65 \%}\right)$; and (iii) with $20 \%$ of the total $\mathrm{N}$ applied in conventional fertigation being $\mathrm{NH}_{4}{ }^{+}$, total $\mathrm{N}$ applied $10.64 \mathrm{mmol} \mathrm{L}^{-1}\left(\mathrm{NS}_{\mathrm{NH}}{ }^{+}\right)$(Table 1). Since fertilizers are salts, to balance ions in the nutrient solution other nutrients in the nutrient solutions were changed.

\subsection{Production: Yield and Quality}

The tomato fruit production was evaluated according to the following parameters: marketable yield, ranked by categories, and unmarketable fruit. Calibration was carried out according to the maximum diameter of the equatorial section [23], according to the following sizing scale: unmarketable (fruit diameter less than $40 \mathrm{~mm}$ ), MMM (40-46 $\mathrm{mm}$ ), MM (47-56 mm), M (57-66 mmm), G (67-80 mm), and GG (over $81 \mathrm{~mm}$ ). Once the fruit was classified, the next step was to determine the fruit fresh weight by means of a COBOS C-400-CS scale. The harvest period started 100 days after transplanting (DAT) and it ended 131 DAT. Data were recorded 107, 117, 124 and 131 DAT. For each date, 10 plants per experimental replication plot were collected to determine yield parameters, and 4 fruits for quality parameters.

Tomato fruit quality was evaluated taking into account: firmness, expressed in $\mathrm{kg}$, total soluble solids content (SSC), expressed in ${ }^{\circ}$ Brix at $20^{\circ} \mathrm{C}$, electrical conductivity (E.C.), expressed in $\mathrm{dS} \mathrm{m}^{-1}, \mathrm{pH}$, and titratable acidity (TA), expressed as meq citric acid $\mathrm{L}^{-1}$ of juice. For this purpose, two opposite slices from each fruit were homogenized, and the filtered juice was used for soluble-solids content (SSC), measured by an Atago N1 refractometer (Atago Co. Ltd., Tokyo, Japan). Total titratable acidity (TA) was determined following the AOAC methodology (1990). The $\mathrm{pH}$ value in the tomato juice was determined with a $\mathrm{pH}$ meter, and firmness was determined with a penetrometer [24].

\subsection{Leachates}

Leachates were collected by means of rigid plastic lysimeters (one per treatment and block); the dimensions were $1.260 \mathrm{~m} \times 0.815 \mathrm{~m} \times 0.50 \mathrm{~m}$. In order to facilitate drainage, polyethylene balls, which are chemically inert, were placed at the bottom, below the lower soil level, which was rebuilt on this base, keeping the structure of the soil layer by layer. The nutrient solutions applied, and leachates obtained, were stored continuously; their volumes were measured weekly, with samples analyzed for the following parameters: $\mathrm{NO}_{3}{ }^{-}, \mathrm{H}_{2} \mathrm{PO}_{4}{ }^{-}$and $\mathrm{K}^{+}[25]$.

\subsection{Water and Nutrient Use Efficiency}

Water use efficiencies (WUE) were estimated as g of marketable tomato fresh weight per liter of water applied $\left(\mathrm{g} \mathrm{L}^{-1}\right)$. Nitrogen, phosphorous and potassium use efficiencies (NUE, PUE and KUE, respectively) were estimated as g of marketable tomato fresh weight per $g$ of nutrient applied $\left(\mathrm{g} \mathrm{g}^{-1}\right)$. 


\subsection{Experimental Design and Statistical Analysis}

The experiment used a randomized block design, where each parameter assessed in each plant was considered as an independent replicate. The experimental design consisted of three treatments and four plots, with one1repetition per block and treatment. Each replication consisted of three rows; the outer rows were considered as the borders. Data and samples were collected from the middle row.

In order to assess the differences among treatments, a One-way Analysis of Variance (ANOVA) and a Least Significant Difference (LSD) test $(p<0.05)$ were used, represented by lower case letters. All the statistical analyses were performed using the Statgraphics Centurion 18 software (Statpoint Technologies Inc., Warrenton, VA, USA).

\section{Results}

Production and Quality

In spite of the fact that there were no significant differences in the marketable yield of GG fruits (Table 2) at 107 and 117 DAT between the treatments $\mathrm{NS}_{65 \%}$ and $\mathrm{NS}_{\mathrm{NH} 4+}$, as well as in G at 107 and 117 DAT, in M at 107 DAT, and in total marketable yield at 107 DAT, no significant differences were found at the end of the cultivation, so neither of the two strategies modified tomato yields, with values of $1.62-1.63,7.48-7.75,0.69-0.82,0.10-0.15$, $0.04-0.05$, and $10.24-10.60 \mathrm{Kg} \mathrm{m}^{-2}$ for GG, G, M, MM, MMM and total marketable yield, respectively, at $131 \mathrm{DAT}$.

Plants under NS and $\mathrm{NS}_{\mathrm{NH}_{4}}$, presented a firmness and SSC significantly higher at 107 and 131 DAT (Table 3). Electrical conductivity (E.C.) was significantly higher under the $\mathrm{NS}_{65 \%}$ and $\mathrm{NS}_{\mathrm{NH} 4+}$ treatments at 107, 117 and 131 DAT. Titratable acidity was significantly higher under NS and $\mathrm{NS}_{\mathrm{NH} 4+}$ at 124 DAT and under NS at 107 and 117 DAT, but there were no significant differences at the end of the cultivation. $\mathrm{pH}$ was also unaffected (Table 3).

Water use efficiency was significantly higher in $\mathrm{NS}_{65} \%$ and $\mathrm{NS}_{\mathrm{NH} 4+}$, with values of 160.97 and $157.78 \mathrm{~g} \mathrm{~L}^{-1}$, respectively, but there were no significant differences between $\mathrm{NS}_{65} \%$ and the control treatment NS (Table 4). The $\mathrm{NS}_{65 \%}$ treatment led to the highest nutrient use efficiencies, these being $390.65 \mathrm{~g} \mathrm{~g}^{-1}$ for N, $678.99 \mathrm{~g} \mathrm{~g}^{-1}$ for P and $298.16 \mathrm{~g} \mathrm{~g}^{-1}$ for $\mathrm{K}$ (1.57, 1.14 and 1.67-fold with respect to the control, respectively). The $\mathrm{NS}_{\mathrm{NH} 4}{ }^{+}$ treatment improved K use efficiency compared to the control, but PUE decreased.

At the beginning of the growing period, leaching of $\mathrm{N}, \mathrm{P}$ and $\mathrm{K}$ was very high for all treatments, and it decreased by the end of the cultivation (Figures 1-3). The N, P and $\mathrm{K}$ dynamics in leaching in $\mathrm{NS}_{65} \%$ and $\mathrm{NS}_{\mathrm{NH} 4}{ }^{+}$were similar during the whole cycle. The amounts of $\mathrm{NO}_{3}{ }^{-}, \mathrm{P}$ and $\mathrm{K}$ leached were affected by the treatment. The highest $\mathrm{NO}_{3}{ }^{-}$and $\mathrm{K}$ leaching was detected in the NS treatment. Leaching in the $\mathrm{NS}_{65} \%$ and $\mathrm{NS}_{\mathrm{NH} 4}{ }^{+}$treatments was 79 and $72 \%$ of $\mathrm{NO}_{3}{ }^{-}$, and 80 and $71 \%$ of $\mathrm{K}$ of the control treatment, respectively. Treatment NS exhibited the lowest $\mathrm{P}$ leaching, showing significant differences with respect to $\mathrm{NS}_{\mathrm{NH} 4}{ }^{+}$. 


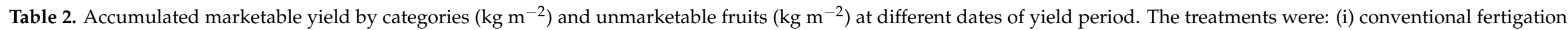

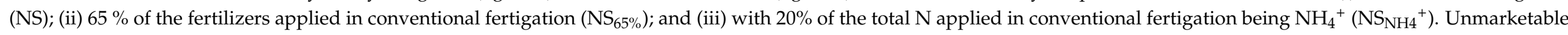

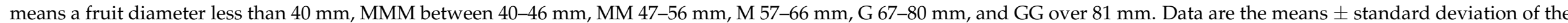

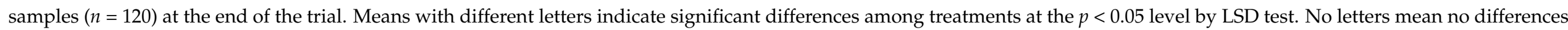
among treatments.

\begin{tabular}{|c|c|c|c|c|c|c|c|c|}
\hline DAT & & GG & G & $\mathbf{M}$ & MM & MMM & Total & Unmarketable \\
\hline \multirow{3}{*}{100} & NS & $0.08 \pm 0.06$ & $0.36 \pm 0.06$ & $0.08 \pm 0.03$ & $0.03 \pm 0.03$ & $0.01 \pm 0.01$ & $0.56 \pm 0.11$ & $0.00 \pm 0.00$ \\
\hline & $\mathrm{NS}_{65 \%}$ & $0.11 \pm 0.07$ & $0.31 \pm 0.08$ & $0.05 \pm 0.01$ & $0.02 \pm 0.01$ & $0.00 \pm 0.01$ & $0.50 \pm 0.13$ & $0.00 \pm 0.00$ \\
\hline & $\mathrm{NS}_{\mathrm{NH} 4}{ }^{+}$ & $0.12 \pm 0.08$ & $0.31 \pm 0.04$ & $0.04 \pm 0.02$ & $0.02 \pm 0.02$ & $0.01 \pm 0.01$ & $0.49 \pm 0.10$ & $0.00 \pm 0.00$ \\
\hline \multirow{3}{*}{107} & NS & $0.18 \pm 0.12 b$ & $1.34 \pm 0.08 \mathrm{a}$ & $0.23 \pm 0.03 \mathrm{a}$ & $0.07 \pm 0.03$ & $0.02 \pm 0.01$ & $1.85 \pm 0.14 \mathrm{a}$ & $0.01 \pm 0.01$ \\
\hline & $\mathrm{NS}_{65 \%}$ & $0.36 \pm 0.10 \mathrm{ab}$ & $1.26 \pm 0.09 \mathrm{a}$ & $0.22 \pm 0.01 \mathrm{a}$ & $0.05 \pm 0.03$ & $0.02 \pm 0.01$ & $1.91 \pm 0.16 \mathrm{a}$ & $0.01 \pm 0.00$ \\
\hline & $\mathrm{NS}_{\mathrm{NH} 4}{ }^{+}$ & $0.43 \pm 0.11 \mathrm{a}$ & $0.93 \pm 0.08 \mathrm{~b}$ & $0.13 \pm 0.02 \mathrm{~b}$ & $0.07 \pm 0.04$ & $0.01 \pm 0.01$ & $1.56 \pm 0.13 b$ & $0.01 \pm 0.01$ \\
\hline \multirow{2}{*}{117} & NS & $0.53 \pm 0.09 \mathrm{~b}$ & $4.68 \pm 0.16 \mathrm{a}$ & $0.34 \pm 0.12$ & $0.11 \pm 0.03$ & $0.04 \pm 0.01$ & $5.69 \pm 0.19$ & $0.03 \pm 0.01 \mathrm{a}$ \\
\hline & $\mathrm{NS}_{\mathrm{NH} 4}{ }^{+}$ & $0.78 \pm 0.12 \mathrm{a}$ & $4.31 \pm 0.19 \mathrm{~b}$ & $0.36 \pm 0.13$ & $0.09 \pm 0.04$ & $0.03 \pm 0.03$ & $5.57 \pm 0.15$ & $0.01 \pm 0.01 \mathrm{~b}$ \\
\hline \multirow{3}{*}{124} & NS & $1.17 \pm 0.11$ & $6.03 \pm 0.21$ & $0.52 \pm 0.04$ & $0.12 \pm 0.03$ & $0.12 \pm 0.01$ & $7.88 \pm 0.16$ & $0.03 \pm 0.01$ \\
\hline & $\mathrm{NS}_{65 \%}$ & $1.33 \pm 0.13$ & $6.19 \pm 0.23$ & $0.49 \pm 0.07$ & $0.09 \pm 0.04$ & $0.09 \pm 0.01$ & $8.12 \pm 0.12$ & $0.02 \pm 0.01$ \\
\hline & $\mathrm{NS}_{\mathrm{NH} 4+}$ & $1.17 \pm 0.14$ & $6.17 \pm 0.19$ & $0.53 \pm 0.05$ & $0.11 \pm 0.02$ & $0.04 \pm 0.03$ & $8.01 \pm 0.15$ & $0.01 \pm 0.01$ \\
\hline \multirow{3}{*}{131} & NS & $1.75 \pm 0.14$ & $7.48 \pm 0.36$ & $0.82 \pm 0.18$ & $0.15 \pm 0.03$ & $0.05 \pm 0.01$ & $10.24 \pm 0.18$ & $0.03 \pm 0.01$ \\
\hline & $\mathrm{NS}_{65 \%}$ & $1.93 \pm 0.19$ & $7.84 \pm 0.29$ & $0.69 \pm 0.16$ & $0.10 \pm 0.04$ & $0.04 \pm 0.01$ & $10.60 \pm 0.13$ & $0.02 \pm 0.01$ \\
\hline & $\mathrm{NS}_{\mathrm{NH} 4}{ }^{+}$ & $1.62 \pm 0.18$ & $7.75 \pm 0.35$ & $0.79 \pm 0.15$ & $0.14 \pm 0.02$ & $0.04 \pm 0.01$ & $10.39 \pm 0.10$ & $0.01 \pm 0.01$ \\
\hline
\end{tabular}




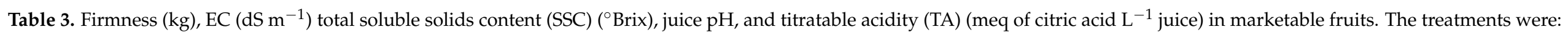

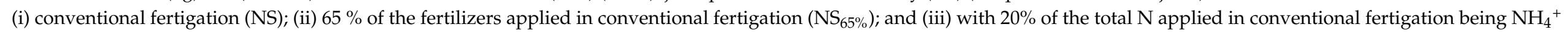

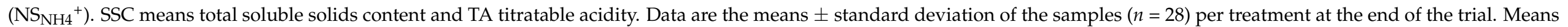
with different letters indicate significant differences among treatments at the $p<0.05$ level by LSD test.

\begin{tabular}{|c|c|c|c|c|c|c|}
\hline DAT & & Firmness & E.C. & $\mathrm{pH}$ & SSC & TA \\
\hline \multirow{3}{*}{107} & NS & $22.80 \pm 1.30 \mathrm{a}$ & $3.25 \pm 0.11 b$ & $4.36 \pm 0.06$ & $4.25 \pm 0.20 \mathrm{a}$ & $0.77 \pm 0.05 a$ \\
\hline & $\mathrm{NS}_{65 \%}$ & $19.80 \pm 1.38 b$ & $3.36 \pm 0.10 \mathrm{ab}$ & $4.42 \pm 0.03$ & $3.75 \pm 0.15 b$ & $0.63 \pm 0.03 b$ \\
\hline & $\mathrm{NS}_{\mathrm{NH} 4}{ }^{+}$ & $23.00 \pm 1.19 \mathrm{a}$ & $3.44 \pm 0.12 \mathrm{a}$ & $4.33 \pm 0.08$ & $4.20 \pm 0.22 \mathrm{a}$ & $0.62 \pm 0.02 b$ \\
\hline \multirow{3}{*}{117} & NS & $19.50 \pm 1.73$ & $2.26 \pm 0.15 b$ & $4.49 \pm 0.09$ & $3.94 \pm 0.13 b$ & $0.76 \pm 0.11 a$ \\
\hline & $\mathrm{NS}_{65 \%}$ & $19.00 \pm 1.82$ & $3.24 \pm 0.15 \mathrm{a}$ & $4.48 \pm 0.06$ & $4.13 \pm 0.14 b$ & $0.64 \pm 0.10 b$ \\
\hline & $\mathrm{NS}_{\mathrm{NH} 4}{ }^{+}$ & $20.00 \pm 1.41$ & $3.41 \pm 0.17 \mathrm{a}$ & $4.53 \pm 0.07$ & $4.58 \pm 0.12 \mathrm{a}$ & $0.62 \pm 0.02 \mathrm{~b}$ \\
\hline \multirow{2}{*}{124} & NS & $23.00 \pm 1.41$ & $3.03 \pm 0.13$ & $4.45 \pm 0.09$ & $4.06 \pm 0.13 b$ & $1.04 \pm 0.15 \mathrm{a}$ \\
\hline & $\mathrm{NS}_{\mathrm{NH} 4}{ }^{+}$ & $25.50 \pm 1.73$ & $3.22 \pm 0.12$ & $4.46 \pm 0.02$ & $4.75 \pm 0.20 \mathrm{a}$ & $1.07 \pm 0.11 \mathrm{a}$ \\
\hline \multirow{3}{*}{131} & NS & $24.75 \pm 1.19 \mathrm{a}$ & $2.70 \pm 0.28 b$ & $4.47 \pm 0.07$ & $4.50 \pm 0.21 \mathrm{a}$ & $1.35 \pm 0.15$ \\
\hline & $\mathrm{NS}_{65 \%}$ & $19.60 \pm 1.23 \mathrm{~b}$ & $3.87 \pm 0.16 \mathrm{a}$ & $4.41 \pm 0.13$ & $3.81 \pm 0.23 b$ & $1.34 \pm 0.05$ \\
\hline & $\mathrm{NS}_{\mathrm{NH} 4}{ }^{+}$ & $25.60 \pm 1.98 \mathrm{a}$ & $3.72 \pm 0.27 \mathrm{a}$ & $4.40 \pm 0.04$ & $4.67 \pm 0.27 \mathrm{a}$ & $1.45 \pm 0.14$ \\
\hline
\end{tabular}


Table 4. Water and nutrient use efficiencies (WUE, expressed as g of marketable tomato fresh weight per liter of water applied, $\mathrm{g} \mathrm{L}^{-1}$ ) (NUE, PUE and KUE, expressed as g of marketable tomato fresh weight per $g$ of nutrient applied, $\mathrm{g} \mathrm{g}^{-1}$ ). The treatments were: (i) conventional fertigation (NS); (ii) $65 \%$ of the fertilizers applied in conventional fertigation $\left(\mathrm{NS}_{65 \%}\right)$; and (iii) with $20 \%$ of the total $\mathrm{N}$ applied in conventional fertigation being $\mathrm{NH}_{4}{ }^{+}\left(\mathrm{NS}_{\mathrm{NH} 4}{ }^{+}\right)$. Data are the means \pm standard deviation of the samples $(n=12)$ per treatment at the end of the trial. Means with different letters indicate significant differences among treatments at the $p<0.05$ level by LSD test.

\begin{tabular}{ccccc}
\hline & WUE & NUE & PUE & KUE \\
\hline $\mathrm{NS}$ & $155.50 \pm 1.15 \mathrm{~b}$ & $248.78 \pm 2.83 \mathrm{~b}$ & $595.38 \pm 6.01 \mathrm{~b}$ & $178.61 \pm 1.34 \mathrm{c}$ \\
$\mathrm{NS}_{65 \%}$ & $160.97 \pm 1.12 \mathrm{a}$ & $390.65 \pm 2.84 \mathrm{a}$ & $678.99 \pm 7.02 \mathrm{a}$ & $298.16 \pm 3.04 \mathrm{a}$ \\
$\mathrm{NS}_{\mathrm{NH} 4}{ }^{+}$ & $157.78 \pm 1.56 \mathrm{ab}$ & $254.80 \pm 3.80 \mathrm{~b}$ & $537.90 \pm 4.53 \mathrm{c}$ & $217.23 \pm 1.95 \mathrm{~b}$ \\
\hline
\end{tabular}
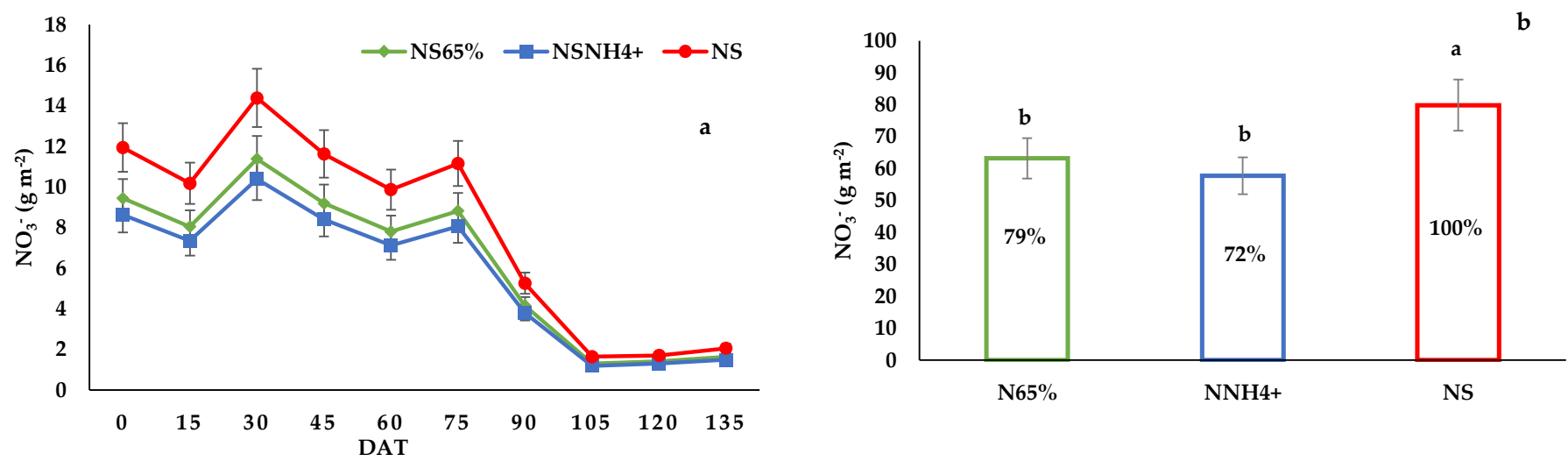

Figure 1. (a) Evolution of $\mathrm{NO}_{3}{ }^{-}$leaching during the cultivation, (b) Total amount of $\mathrm{NO}_{3}{ }^{-}$leached by the tomato crop, with the percentage of contamination reduction of the fertigation strategies assayed compared to standard fertigation. The columns show the mean values, and the bars the standard deviation of each treatment $(n=12)$ at the end of the trial. Different letters indicate significant differences among treatments at the $p<0.05$ level, based on the LSD test.
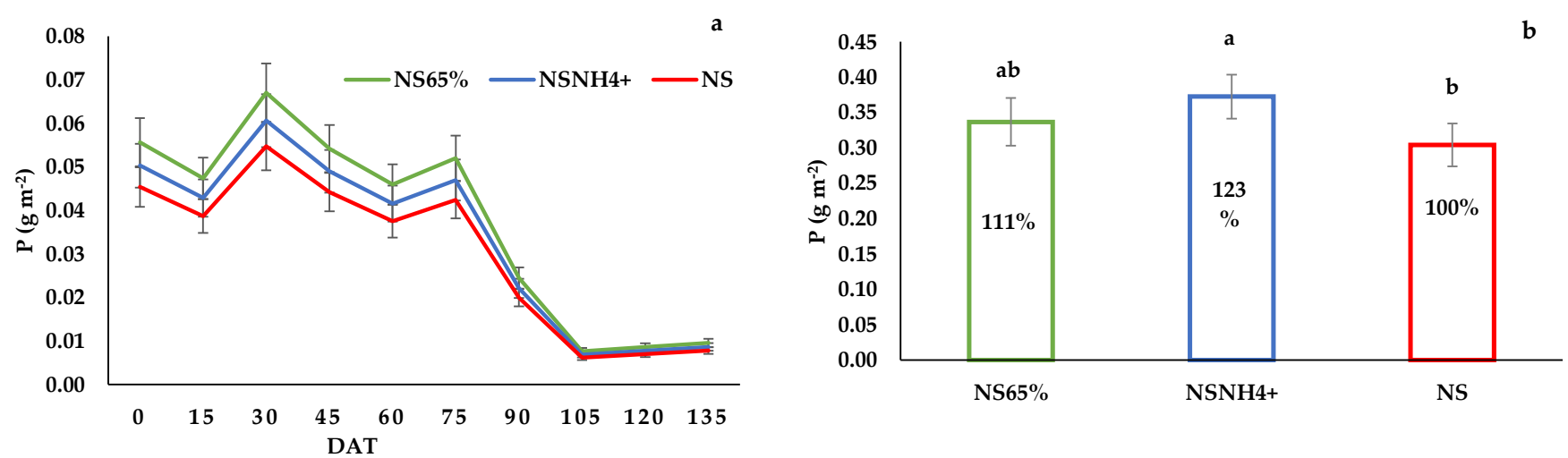

Figure 2. (a) Evolution of P leaching during the cultivation, (b) Total amount of P leached by the tomato crop, with the percentage of contamination reduction of the fertigation strategies assayed compared to standard fertigation. The columns show the mean values, and the bars the standard deviation of each treatment $(n=12)$ at the end of the trial. Different letters indicate the significant differences among treatments at the $p<0.05$ level, based on the LSD test. 

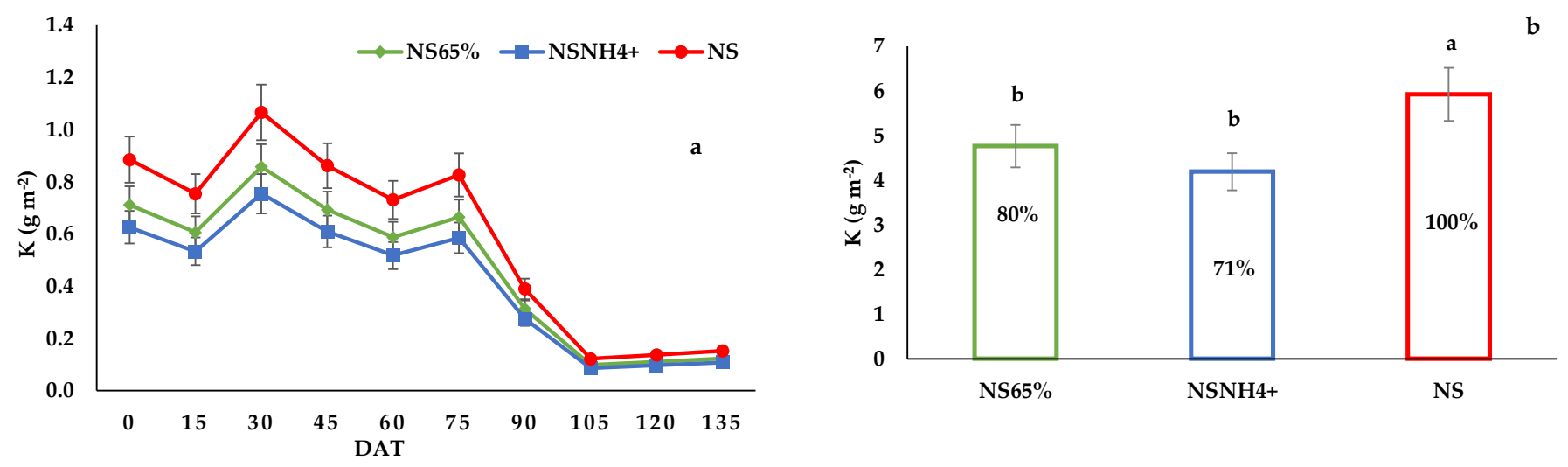

Figure 3. (a) Evolution of K leaching during the cultivation, (b) Total amount of $\mathrm{K}$ leached by the tomato crop, with the percentage of contamination reduction of the fertigation strategies assayed compared to the standard fertigation. The columns show the mean values, and the bars the standard deviation of each treatment $(n=12)$ at the end of the trial. Different letters indicate the significant differences among treatments at the $p<0.05$ level, based on the LSD test.

\section{Discussion}

Nitrogen is the most limiting nutrient for plant growth and potential yield [26]. Pardossi [27] identified the usual range (14 to $15 \mathrm{mM}$ ) for greenhouse vegetable cultivation in southern European countries. The concentration of $\mathrm{N} 11 \mathrm{mM}$ is frequently applied in protected vegetable cultivation in the Maresme region, located near Barcelona, Spain [28]. In Southeastern Spain, the usual $\mathrm{NO}_{3}{ }^{-}$concentration applied in the nutrient solution is between 12-14 mM [29]. Similar values have been used in our trial. It is important to point out that the proposed strategies $\left(\mathrm{NO}_{3}{ }^{-}\right.$reduction and substitution of part of the $\mathrm{NO}_{3}{ }^{-}$ used with $\mathrm{NH}_{4}{ }^{+}$) did not reduce the yield obtained. These results agree with those obtained in other studies. Wang et al. [30] reported that high $\mathrm{N}$ input for vegetables grown in greenhouses did not increase yield significantly. Soto et al. [29] studied four different mineral $\mathrm{N}$ fertilizer rates $\left(\mathrm{N}_{1}: 0.6-1.1 \mathrm{mM} ; \mathrm{N}_{2}: 4.4-5.2 \mathrm{mM} ; \mathrm{N}_{3}\right.$ : $\left.13.4-13.6 \mathrm{mM} ; \mathrm{N}_{4}: 20.5-21.7 \mathrm{mM}\right)$ and observed that the highest total and marketable fresh fruit production was obtained with the $\mathrm{N}_{2}$ treatment in the autumn-winter crop. Du et al. [26] also found that the application of $250 \mathrm{~kg} \mathrm{~N} \mathrm{ha}^{-1}$ (intermediate level) produced the highest yield, but an application above this level did not continue to increase yield, which was likely because the higher $\mathrm{N}$ application extended the crop vegetative growth and decreased the transport of photosynthates to the fruit, eventually decreasing the harvest index. However, Segura et al. [31] found that the fertigation level (from 3.6 to $14.2 \mathrm{mM} \mathrm{NO}_{3}{ }^{-}$) increased yield, fruit number, and number of trusses of the marketable tomato "Pitenza" under fertigation during all the stages of cultivation, with yields from 3.31 to $4.92 \mathrm{~g} \mathrm{~m}^{-2}$, respectively, but there was no effect on unmarketable yield.

In the present study, Lycopersicum esculentum Mill. cv. Forteza plants under the $\mathrm{NH}_{4}{ }^{+}$ treatment did not reduce yield. Plants may save energy by taking up organic $\mathrm{N}_{\text {or }} \mathrm{NH}_{4}^{+}$ instead of $\mathrm{NO}_{3}{ }^{-}$, which may lead to a better carbohydrate status in the plant tissues, and the yield of marketable red tomatoes (Lycopersicon esculentum Mill. cv "Armada", Enza Zaden) showed no significant differences between different $\mathrm{NO}_{3}{ }^{-}: \mathrm{NH}_{4}{ }^{+}$ratios in the nutrient solution [32]. In general, $\mathrm{NH}_{4}{ }^{+}$would be the preferred $\mathrm{N}$ source for plants, as it requires less energy to absorb and is a key intermediate in many metabolic reactions, with plants shown to assimilate $\mathrm{NH}_{4}{ }^{+}$efficiently under a moderate $\mathrm{NH}_{4}{ }^{+}$concentration [33]. Nevertheless, most species develop toxicity symptoms when grown under moderate to high levels of $\mathrm{NH}_{4}{ }^{+}$[34]. Navarro et al. [35] found that the applications of $\mathrm{NH}_{4}{ }^{+}$produced the lowest marketable yield in tomato grown in a hydroponic culture in a greenhouse, by reducing the size and number of marketable fruits compared to the control treatment. This reduction was due to an increase in the number of fruits with blossom-end rot, probably caused by a low $\mathrm{Ca}^{2+}$ concentration in the fruits. Flores et al. [36] also observed that increasing the $\mathrm{NH}_{4}{ }^{+}$concentration in the nutrient solutions decreased tomato yield. 
Applied fertilizer regimes aim to determine fruit quality parameters [37]. According to our results, significant differences related to the quality parameters were observed according to the applied fertilizer treatments. The increase in the fertilization level did not affect the tomato juice $\mathrm{pH}$, but it affected the firmness, EC, SSC and TA. An increase in the nitrogen level increased firmness 107 and 131 DAT, SSC 107 and 131 DAT and TA 107,117 and 124 DAT. According to the literature, the effect of the nitrogen level has shown contradictory results. Davies and Winsor [38] and Thakur et al. [39] reported a positive relationship between $\mathrm{N}$ concentration and fruit acidity. Ferreira et al. [40] reported a mean value of $3.93{ }^{\circ}$ Brix, lower than that found in this study, although it did not change with increasing doses. N. Soto et al. (2015) did not find a significant effect on firmness under increasing $\mathrm{N}$ treatments. On the other hand, increasing levels of $\mathrm{N}$ negatively influenced the levels of ascorbic acid and titrate acidity [19], but the values of soluble solids and the $\mathrm{pH}$ did not change. Nevertheless, Segura et al. [31] found that firmness and SSC increased throughout the time cycle, independently of the fertilization level. In the study by Porto et al. [41], nitrogen fertilization levels did not influence tomato fruit firmness nor the SSC content. Contrarily, the supply of $\mathrm{N}$ reduced titratable acidity, increasing the SSC/TA ratio and changing the flavor of the fruit. In a study conducted by Bénard et al. [42], it was found that an increase of $\mathrm{N}$ fertilization can affect total TA, contributing to a reduction in the citric acid content in tomato fruits. The use of $20 \% \mathrm{NH}_{4}{ }^{+}$as an $\mathrm{N}$ source increased EC (107, 117, 131 DAT) and SSC (117 and 124 DAT) and decreased TA (107 and 117 DAT) compared to the control. Navarro et al. [35] also observed that, in tomato fruits, some quality parameters, such as firmness, $\mathrm{pH}$, TSS, TSS/acidity ratio and glucose content were affected by the addition of $\mathrm{NH}_{4}{ }^{+}$.

Water use efficiency decreased with the increasing $\mathrm{N}$ level. These results disagreed with those obtained by Al-Khader et al. [43], who found an improvement in WUE at high levels of $\mathrm{N}$ in watermelon. Likewise, Badr et al. [44] found the same results in tomato plants cultivated with drip irrigation, with WUE being greater at the highest $\mathrm{N}$ rate. Similarly, in tomato plants cultivated in the open-field in fall, iWUE was lower $\left(21.88 \mathrm{~kg} \mathrm{~m}^{-3}\right)$ with $134 \mathrm{~kg} \mathrm{ha}^{-1} \mathrm{~N}$, due to a lower yield, compared with that occurring with application rates of $179-269 \mathrm{~kg} \mathrm{ha}^{-1} \mathrm{~N}\left(29.83-32.85 \mathrm{~kg} \mathrm{~m}^{-3}\right)$; nevertheless, in spring there were no significant differences [45]. Optimizing $\mathrm{N}$ supplies is very important in order to improve NUE. According to our results, NUE decreased with increasing N levels [6,44], which was perhaps due to the limitation of $\mathrm{N}$ uptake by the plants and the sink capacity, resulting in plant saturation [26]. Excessive $\mathrm{N}$ uptake no longer contributed to yield increase and production efficiency, but $\mathrm{N}$ instead accumulated in store organs, which might also be ascribed to the lowest NUE of the high N applied [26]. Wang and Xing [46] found a negative correlation between $\mathrm{N}$ use efficiency and levels of $\mathrm{N}$ fertilizer application, showing that the $\mathrm{N}$ recovery efficiency decreased with the increase in $\mathrm{N}$ fertilizer. Nevertheless, the results obtained by Cheng et al. [47] in tomato plants cultivated in soil must be considered. They applied high $\left(250 \mathrm{~kg} \mathrm{ha}^{-1}\right)$, middle $\left(175 \mathrm{~kg} \mathrm{ha}^{-1}\right)$ and low $\left(125 \mathrm{~kg} \mathrm{ha}^{-1}\right)$ levels of $\mathrm{N}$-fertilizer and found NUE values of $0.49-0.55,0.51-0.59$ and $0.46-0.51$, respectively. These results imply that there is a range of $\mathrm{N}$ application which optimizes the NUE.

Moreover, the $\mathrm{NS}_{65} \%$ treatment improved both PUE and KUE. These results agree with those obtained by Lajtha and Klein [48], who found a decrease in P use efficiency when increasing $\mathrm{N}$ availability in Larrea tridentata, and $\mathrm{Wu}$ et al. [49] found similar results in Sophora davidii seedlings. Likewise, Martí and Mills [50] found a decreased in K-use efficiency with increments in the $\mathrm{N}$ rate application. Contrary to our results, ammonium sulfate $\left(\mathrm{NH}_{4}\right)_{2} \mathrm{SO}_{4}$ proved advantageous in terms of $\mathrm{N}$ use efficiency in wheat due to the higher crop $\mathrm{N}$ uptake and lower $\mathrm{N}$ loss [51]. $20 \%$ of total $\mathrm{N}$ applied in conventional fertigation as $\mathrm{NH}_{4}{ }^{+}$decreased PUE and increased KUE compared to the control. Roberts and Johnston [52] considered that fertilizers containing ammoniacal N, N and P interact, enhancing $\mathrm{P}$ uptake and improving nutrient use efficiency for both nutrients. This statement disagrees with our results. On the other hand, Xu et al. [53] found an increase in KUE in 
sweet pepper under $\mathrm{N}$ fertilization with $15-30 \%$ of $\mathrm{NH}_{4}+$ related to $\mathrm{NO}_{3}$ - fertilization; this is similar to the results obtained in our study.

In our trial, the volume of leachate was $716 \mathrm{~m}^{3} \mathrm{ha}^{-1}$ (24\% of applied water). This value is lower than the value estimated by Van Widen [54] in hydroponic crops in the Mediterranean area (2000 and $3000 \mathrm{~m} 3 \mathrm{ha}^{-1}$ ), and similar to those found by Ramos [55] in the same area. The leaching volume in a tomato crop in the winter period, from September to April, was $1250 \mathrm{~m}^{3} \mathrm{ha}^{-1}$ in a cultivation cycle of 246 days [56]. Nitrate, $\mathrm{P}$ and $\mathrm{K}$ leaching were higher from the beginning of cultivation to 75 DAT compared to the leaching of these elements at the end of the cycle (Figures 1a, 2a and 3a); this fact could be related to the imbalance between the hydric and nutritive demand of the plants from the transplanting to the full production stage.

Comparing the total amount of nutrients leached with the control (Figures $1 b, 2 b$ and $3 b$ ), $\mathrm{NO}_{3}{ }^{-}$and $\mathrm{K}$ leaching were lower with the $\mathrm{NS}_{65} \%$ and $\mathrm{NS}_{\mathrm{NH}}{ }^{+}$strategies. Nevertheless, $\mathrm{P}$ leaching was higher with the $\mathrm{NS}_{\mathrm{NH} 4}{ }^{+}$strategy. Nitrate leachates, from protected and openfield horticulture, are important contributors to groundwater pollution and eutrophication. The standard treatment leached $798 \mathrm{~kg} \mathrm{ha}^{-1}$ of $\mathrm{NO}_{3}{ }^{-}$, lower than the value found by Lao and Jiménez [56]. Nevertheless, an important reduction of $\mathrm{NO}_{3}{ }^{-}$losses of 79 and $72 \%$ compared to NS (100\%) in the $\mathrm{NS}_{65} \%$ and $\mathrm{NS}_{\mathrm{NH} 4}{ }^{+}$treatments, respectively, have been estimated (Figure $1 \mathrm{~b}$ ). There are several reports indicating the positive effects of reduced $\mathrm{N}$ applied on $\mathrm{N}$ leaching. According to life cycle assessment, Muñoz et al. [57] found that a reduction of $36 \%$ in $\mathrm{N}$ fertilizers leads to a $60 \%$ decrease in the potential impact of eutrophication, a $50 \%$ decrease in the potential impact of climate change, and a $45 \%$ decrease in the potential impact of photochemical oxidants; moreover, a reduction in $\mathrm{NO}_{3}{ }^{-}$concentration applied from $11 \mathrm{~mol} \mathrm{~L}^{-1}$ to $7 \mathrm{mmol} \mathrm{L}^{-1}$, with a drainage volume of $30 \%$, caused a $70 \%$ decrease in $\mathrm{NO}_{3}{ }^{-}$leaching, a value which is 2.5 times greater than our results. In general, when $\mathrm{N}$ input is greater than the optimal rate, yield may not increase further, but nutrient leaching may increase linearly or exponentially [30]. Moreover, the amount of nitrogen supplied to the crop by irrigation water, which was shown to be striking, also needs to be taken into account [58]. If the rate of $\mathrm{NO}_{3}{ }^{-}$uptake by the crop is not great enough, it accumulates in the root zone and is easily leached by irrigation water and rainwater into the deeper soil layers, finally reaching the groundwater [59]. Nitrate is highly mobile and easily leaches, due to its negative charge. Thus, excessive applications of $\mathrm{N}$ might lead to $\mathrm{NO}_{3}{ }^{-}$contamination of surface water and groundwater [60]. However, $\mathrm{NH}_{4}{ }^{+}$is fixed by the mineral fraction of the soil and it is relatively difficult to leach. Li et al. [51] reported that the $\left(\mathrm{NH}_{4}\right)_{2} \mathrm{SO}_{4}$ supply proves advantageous in terms of grain yield and $\mathrm{N}$ use efficiency in wheat, due to the higher crop $\mathrm{N}$ uptake and lower $\mathrm{N}$ loss.

However, leaching of $\mathrm{K}$ and $\mathrm{P}$ was rather scant compared to $\mathrm{NO}_{3}{ }^{-}$. The standard treatment caused $30.4 \mathrm{~kg} \mathrm{ha}^{-1}$ of $\mathrm{P}$ losses; this may be due to phosphate precipitation in the soil [56], a typical response under higher soil solution $\mathrm{pH}$ [61]. Nevertheless, an important increase in P losses of 111 and 123\% compared to the NS treatment (100\%) in the $\mathrm{NS}_{65 \%}$ and $\mathrm{NS}_{\mathrm{NH} 4+}$ treatments, respectively, have been estimated (Figure $1 \mathrm{~b}$ ), but there were no significant differences between $\mathrm{NS}_{65} \%$ and the control. This greater loss of $\mathrm{P}$ under the $\mathrm{NS}_{\mathrm{NH} 4+}$ treatment may be due to the nitrification of $\mathrm{NH}_{4}{ }^{+}$at the root-zone level, which is associated with the acidification of the medium which can increase the solubility of phosphates, and these can be carried away by the draining solution flow [18]. In strongly acidic soils, the formation of iron and aluminum phosphate minerals results in the reduced solubility of $\mathrm{P}$, improving as the $\mathrm{pH}$ approaches close to neutral [62]. However, this maximum solubility and plant availability of $\mathrm{P}$ at $\mathrm{pH} 6.5$ declines again as the $\mathrm{pH}$ increases into the alkaline range [62].

The standard treatment presented $59.2 \mathrm{~kg} \mathrm{ha}^{-1}$ of $\mathrm{K}$ losses, which could be due to the blockage of $\mathrm{K}$ in the exchangeable bases [56]. The high fixation and low leaching of $\mathrm{K}$ have also been referred to earlier [63]. Therefore, the intensive use of fertilizers may increase $\mathrm{N}$ and $\mathrm{K}$ concentrations in groundwater $[64,65]$. 


\section{Conclusions}

The strategies tested did not modify the tomato fruit yield. Nitrate reduction caused firmness and a ${ }^{\circ}$ Brix reduction, as well as a diminution of the titratable acidity up to 124 DAT. Nevertheless, these effects were not found with the replacement of $\mathrm{NO}_{3}{ }^{-}$by $\mathrm{NH}_{4}{ }^{+}$. However, the reduction in fertilizer inputs significantly improved water and nutrient $(\mathrm{N}, \mathrm{P}$ and $\mathrm{K})$ use efficiency. Contamination was greatly reduced from 90 DAT on in the strategies tested as well as in the control, following the same pattern during cultivation. Nevertheless, both strategies caused a reduction in $\mathrm{NO}_{3}{ }^{-}$and $\mathrm{K}$ contamination, but $P$ pollution increased. The strategies proposed are a useful tool for more sustainable fertigation management.

Author Contributions: Conceptualization, M.T.L. and S.J.-B.; methodology, M.T.L.; software, S.J.-B.; validation, M.T.L. and S.J.-B.; formal analysis, B.M.P.; investigation, B.M.P.; resources, M.T.L.; data curation, M.T.L. and S.J.-B.; writing—original draft preparation, B.M.P.; writing—review and editing, M.T.L. and S.J.-B.; visualization, M.T.L.; supervision, M.T.L. and S.J.-B.; project administration, M.T.L.; funding acquisition, M.T.L. All authors have read and agreed to the published version of the manuscript.

Funding: This research received no external funding.

Data Availability Statement: No new data were created or analyzed in this study. Data sharing is not applicable to this article.

Conflicts of Interest: The authors declare no conflict of interest.

\section{References}

1. Garcia-Caparros, P.; Contreras, J.I.; Baeza, R.; Segura, M.L.; Lao, M.T. Integral Management of Irrigation Water in Intensive Horticultural Systems of Almería. Sustainability 2017, 9, 2271. [CrossRef]

2. Duque-Acevedo, M.; Belmonte-Ureña, L.J.; Plaza-Úbeda, J.A.; Camacho-Ferre, F. The Management of Agricultural Waste Biomass in the Framework of Circular Economy and Bioeconomy: An Opportunity for Greenhouse Agriculture in Southeast Spain. Agronomy 2020, 10, 489. [CrossRef]

3. Sayadi-Gmada, S.; Rodríguez-Pleguezuelo, C.R.; Rojas-Serrano, F.; Parra-López, C.; Parra-Gómez, S.; García-García, M.D.C.; García-Collado, R.; Lorbach-Kelle, M.B.; Manrique-Gordillo, T. Inorganic Waste Management in Greenhouse Agriculture in Almeria (SE Spain): Towards a Circular System in Intensive Horticultural Production. Sustainability 2019, 11, 3782. [CrossRef]

4. Thompson, R.; Martínez-Gaitan, C.; Gallardo, M.; Giménez, C.; Fernández, M. Identification of irrigation and N management practices that contribute to nitrate leaching loss from an intensive vegetable production system by use of a comprehensive survey. Agric. Water Manag. 2007, 89, 261-274. [CrossRef]

5. Castro, A.J.; López-Rodríguez, M.D.; Giagnocavo, C.; Gimenez, M.; Céspedes, L.; La Calle, A.; Gallardo, M.; Pumares, P.; Cabello, J.; Rodríguez, E.; et al. Six Collective Challenges for Sustainability of Almería Greenhouse Horticulture. Int. J. Environ. Res. Public Health 2019, 16, 4097. [CrossRef]

6. Jalpa, L.; Mylavarapu, R.S.; Hochmuth, G.J.; Wright, A.L.; Van Santen, E. Apparent Recovery and Efficiency of Nitrogen Fertilization in Tomato Grown on Sandy Soils. HortTechnology 2020, 30, 204-211. [CrossRef]

7. Wang, S.; Bai, X.; Zhou, J.; Chen, Z. Reducing Nutrient and Irrigation Rates in Solar Greenhouse without Compromising Tomato Yield. HortScience 2019, 54, 1593-1599. [CrossRef]

8. Carpenter, S.R.; Caraco, N.F.; Correll, D.L.; Howarth, R.W.; Sharpley, A.N.; Smith, V.H. Nonpoint pollution of surface waters with phosphorus and nitrogen. Ecol. Appl. 1998, 8, 559-568. [CrossRef]

9. Trandel, M.A.; Vigardt, A.; Walters, S.A.; Lefticariu, M.; Kinsel, M. Nitrogen Isotope Composition, Nitrogen Amount, and Fruit Yield of Tomato Plants Affected by the Soil-Fertilizer Types. ACS Omega 2018, 3, 6419-6426. [CrossRef] [PubMed]

10. Juang, T.C.; Wang, M.K.; Chen, H.J.; Tan, C.C. Ammonium Fixation by Surface Soils and Clays. Soil Sci. 2001, 166, 345-352. [CrossRef]

11. Nieder, R.; Benbi, D.K.; Scherer, H.W. Fixation and defixation of ammonium in soils: A review. Biol. Fertil. Soils 2011, 47, 1-14. [CrossRef]

12. Liu, Y.-L.; Zhang, B.; Li, C.-L.; Hu, F.; Velde, B. Long-Term Fertilization Influences on Clay Mineral Composition and Ammonium Adsorption in a Rice Paddy Soil. Soil Sci. Soc. Am. J. 2008, 72, 1580-1590. [CrossRef]

13. Guo, P.-C.; Bohring, J.; Scherer, H.W. Verhalten von Dünger-NH4 in Böden unterschiedlicher tonmineralischer Zusammensetzung im Inkubationsversuch. J. Plant Nutr. Soil Sci. 1983, 146, 752-759. [CrossRef]

14. Mancino, C.F.; Troll, J. Nitrate and Ammonium Leaching Losses from N Fertilizers Applied to 'Penncross' Creeping Bentgrass. HortScience 1990, 25, 194-196. [CrossRef] 
15. Wójcik, P. Ecological Impact of Nitrogen Fertilization. J. Fruit Ornam. Plant Res. 2001, 9, 117-120. Available online: http:/ /www. inhort.pl/journal-of-fruit-and-ornamental--plant-research/journal-contents/vol.-ix-no.-1-4-2001?printpdf=true (accessed on 20 January 2021).

16. Bending, G.D.; Turner, M.K.; Burns, I.G. Fate of nitrogen from crop residues as affected by biochemical quality and the microbial biomass. Soil Biol. Biochem. 1998, 30, 2055-2065. [CrossRef]

17. Wang, X.-X.; Liu, S.; Zhang, S.; Li, H.; Maimaitiaili, B.; Feng, G.; Rengel, Z. Localized ammonium and phosphorus fertilization can improve cotton lint yield by decreasing rhizosphere soil $\mathrm{pH}$ and salinity. Field Crop. Res. 2018, 217, 75-81. [CrossRef]

18. Mengel, K.; Kirkby, E.A. Principles of Plant Nutrition; International Potash Institute: Ittigen, Switzerland, 1987.

19. Reboucas, T.; Porto, J.; Jesus, J.; Moraes, M. Effects of different nitrogen sources and levels on tomato fruit quality. Acta Hortic. 2015, 1106, 79-84. [CrossRef]

20. Assunção, N.S.; Silva, N.O.; Fernandes, F.L.; De Aquino, L.A.; Fernandes, M.E.D.S. Physico-chemical characteristics and productivity of tomato plants in function of nitrogen sources and doses. Biosci. J. 2020, 36, 1274-1282. [CrossRef]

21. Lao, M.T. The mulching sandy soil and their management fertigation in horticultural production. Trends Soil Sci. 2004, 3, 71-82.

22. Fernández, M.D.; Orgaz, F.; Pérez, J.; Bonachela, S.; Gallardo, M. Programación del Riego de Cultivos Hortícolas Bajo Invernadero en el Sudeste Español; Cajamar: Almería, Spain, 2001.

23. European Commission. The Tomato Market in the EU: Vol. 1: Production, Areas and Yields. 1 (October), 13. 2019. Available online: https:/ / ec.europa.eu/info/sites/info/files/food-farming-fisheries/farming/documents/tomatoes-production_en.pdf (accessed on 1 January 2021).

24. AOAC. Official Methods of Analysis of the Association of Official Analytical Chemists, 15th ed.; Association of Official Analytical Chemists: Arlington, VA, USA, 1990; pp. 1058-1059.

25. MAPA (Ministerio de Agricultura, Pesca y Alimentación). Métodos Oficiales de Análisis; Tomo III; Secretaría General Técnica: Madrid, Spain, 1994.

26. Du, Y.-D.; Cao, H.-X.; Liu, S.-Q.; Gu, X.-B.; Cao, Y.-X. Response of yield, quality, water and nitrogen use efficiency of tomato to different levels of water and nitrogen under drip irrigation in Northwestern China. J. Integr. Agric. 2017, 16, 1153-1161. [CrossRef]

27. Pardossi, A. The Management of Plant Mineral Nutrition in Soilless Culture. In Improvement of Water Use Efficiency in Protected Crops; Fernández, M., Mínguez, P.L., Gómez, I.M., Eds.; Dirección General de Investigación y Formación Agraria de la Junta de Andalucía: Seville, Spain, 2005; p. 122.

28. Muñoz, P.; Ariño, J.; Montero, J.I.; Antón, A. Cascade crops: A method proposed for increasing sustainability in el Maresme. In Agriculture and Energy: Case Studies in the Agro-Industrial Sector; Institut de Recerca i Tecnologia Agroalimentàries: Barcelona, Spain, 2005; Volume 1, pp. 468-472.

29. Soto, F.; Gallardo, M.; Thompson, R.B.; Peña-Fleitas, M.T.; Padilla, F.M. Consideration of total available N supply reduces N fertilizer requirement and potential for nitrate leaching loss in tomato production. Agric. Ecosyst. Environ. 2015, $200,62-70$. [CrossRef]

30. Wang, Y.; Ying, H.; Yin, Y.; Zheng, H.; Cui, Z. Estimating soil nitrate leaching of nitrogen fertilizer from global meta-analysis. Sci. Total. Environ. 2019, 657, 96-102. [CrossRef] [PubMed]

31. Segura, M.L.; Contreras, J.I.; Salinas, R.; Lao, M.T. Influence of Salinity and Fertilization Level on Greenhouse Tomato Yield and Quality. Commun. Soil Sci. Plant Anal. 2009, 40, 485-497. [CrossRef]

32. Heeb, A.; Lundegårdh, B.; Ericsson, T.; Savage, G.P. Effects of nitrate-, ammonium-, and organic-nitrogen-based fertilizers on growth and yield of tomatoes. J. Plant Nutr. Soil Sci. 2005, 168, 123-129. [CrossRef]

33. Vega-Mas, I.; Pérez-Delgado, C.M.; Marino, D.; Fuertes-Mendizábal, T.; González-Murua, C.; Márquez, A.J.; Betti, M.; Estavillo, J.M.; González-Moro, M.B. Elevated CO2 induces root defensive mechanisms in tomato plants when dealing with ammonium toxicity. Plant Cell Physiol. 2017, 58, 2112-2125. [CrossRef] [PubMed]

34. Britto, D.T.; Siddiqi, M.Y.; Glass, A.D.M.; Kronzucker, H.J. Futile transmembrane NH4+ cycling: A cellular hypothesis to explain ammonium toxicity in plants. Proc. Natl. Acad. Sci. USA 2001, 98, 4255-4258. [CrossRef]

35. Navarro, J.M.; Flores, P.; Carvajal, M.; Martinez, V. Changes in quality and yield of tomato fruit with ammonium, bicarbonate and calcium fertilisation under saline conditions. J. Hortic. Sci. Biotechnol. 2005, 80, 351-357. [CrossRef]

36. Flores, P.; Navarro, J.M.; Carvajal, M.; Cerdá, A.; Martínez, V. Tomato yield and quality as affected by nitrogen source and salinity. Agronomie 2003, 23, 407-418. [CrossRef]

37. Petropoulos, S.A.; Fernandes, Â.; Xyrafis, E.; Polyzos, N.; Antoniadis, V.; Barros, L.; Ferreira, I.C. The optimization of nitrogen fertilization regulates crop performance and quality of processing tomato (Solanum lycopersicum L. cv. Heinz 3402). Agronomy 2020, 10, 715. [CrossRef]

38. Davies, J.N.; Winsor, G.W. Effect of nitrogen, phosphorus, potassium, magnesium and liming on the composition of tomato fruit. J. Sci. Food Agric. 1967, 18, 459-466. [CrossRef]

39. Thakur, B.R.; Singh, R.K.; Nelson, P.E. Quality attributes of processed tomato products: A review. Food Rev. Int. 1996, 12, 375-401. [CrossRef]

40. Ferreira, M.M.M.; Ferreira, G.B.; Fontes, P.C.R.; Dantas, J.P. Qualidade do tomate em função de doses de nitrogênio e da adubação orgânica em duas estações. Hortic. Bras. 2006, 24, 141-145. [CrossRef]

41. Porto, J.S.; Reboucas, T.N.H.; Moraes, M.O.B.; Bomfim, M.P.; Lemos, O.L.; Luz, J.M.Q. Quality and Antioxidant activity of tomato cultivated under different sources and doses of nitrogen. Rev. Caatinga 2016, 29, 780-788. [CrossRef] 
42. Bénard, C.; Gautier, H.; Bourgaud, F.; Grasselly, D.; Navez, B.; Caris-Veyrat, C.; Weiss, M.; Génard, M. Effects of low nitrogen supply on tomato (Solanum lycopersicum L.) fruit yield and quality with special emphasis on sugars, acids, ascorbate, carotenoids, and phenolic compounds. J. Agric. Food Chem. 2009, 57, 4112-4123. [CrossRef] [PubMed]

43. AlKhader, A.M.F.; Qaryouti, M.M.; Okasheh, T.Y.M. Effect of nitrogen on yield, quality, and irrigation water use efficiency of drip fertigated grafted watermelon (Citrullus lanatus) grown on a calcareous soil. J. Plant Nutr. 2019, 42, 737-748. [CrossRef]

44. Badr, M.A.; El-Tohamy, W.A.; Hussein, S.D.A.; Grud, N. Tomato fruit yield and nitrogen use efficiency as affected by drip irrigation method and rate of nitrogen in a hot dry climate. J. Appl. Sci. Res. 2012, 8, 4486-4495. [CrossRef]

45. Ayankojo, I.T.; Morgan, K.T.; Kadyampakeni, D.M.; Liu, G.D. Tomato Growth, Yield, and Root Development, Soil Nitrogen and Water Distribution as Affected by Nitrogen and Irrigation Rates on a Florida Sandy Soil. HortScience 2020, 55, 1-12. [CrossRef]

46. Wang, X.; Xing, Y. Effects of Irrigation and Nitrogen Fertilizer Input Levels on Soil-n Content and Vertical Distribution in Greenhouse Tomato (Lycopersicum esculentum Mill.). Scientifica 2016, 2016, 1-13. [CrossRef]

47. Chen, N.; Li, X.; Šimůnek, J.; Shi, H.; Hu, Q.; Zhang, Y. Evaluating soil nitrate dynamics in an intercropping dripped ecosystem using HYDRUS-2D. Sci. Total. Environ. 2020, 718, 137314. [CrossRef]

48. Lajtha, K.; Klein, M. The effect of varying nitrogen and phosphorus availability on nutrient use by Larrea tridentata, a desert evergreen shrub. Oecologia 1988, 75, 348-353. [CrossRef]

49. Wu, F.; Bao, W.; Zhou, Z.; Wu, N. Carbon accumulation, nitrogen and phosphorus use efficiency of Sophora davidii seedlings in response to nitrogen supply and water stress. J. Arid. Environ. 2009, 73, 1067-1073. [CrossRef]

50. Martí, H.R.; Mills, H.A. Nitrogen and potassium nutrition affect yield, dry weight partitioning, and nutrient-use efficiency of sweet potato. Commun. Soil Sci. Plant Anal. 2002, 33, 287-301. [CrossRef]

51. Li, H.; Mei, X.; Nangia, V.; Guo, R.; Liu, Y.; Hao, W.; Wang, J. Effects of different nitrogen fertilizers on the yield, water- and nitrogen-use efficiencies of drip-fertigated wheat and maize in the North China Plain. Agric. Water Manag. 2021, 243, 106474. [CrossRef]

52. Roberts, T.L.; Johnston, A.E. Phosphorus use efficiency and management in agriculture. Resour. Conserv. Recycl. 2015, 105, $275-281$. [CrossRef]

53. Xu, G.; Wolf, S.; Kafkafi, U. Ammonium on potassium interaction in sweet pepper. J. Plant Nutr. 2002, 25, 719-734. [CrossRef]

54. Van Winden, C. Soilless culture technique and its relation to the greenhouse climate. Acta Hortic. 1988, 229, 125-132. [CrossRef]

55. Ramos, C. La hidroponía y el medio ambiente. In Cultivos sin Suelo; Canovas, F., Díaz, J.R., Eds.; Instituto de Estudios Almerienses and FIAPA: Almeria, Spain, 1993; pp. 312-363.

56. Lao, M.T.; Jiménez, S. Leaching of nutrients in greenhouse cultivation of tomato crop in the Mediterranean area under different fertigation managements. J. Food Agric. Environ. 2004, 2, 370-375.

57. Muñoz, P.; Antón, A.; Paranjpe, A.; Ariño, J.; Montero, J.I. High decrease in nitrate leaching by lower N input without reducing greenhouse tomato yield. Agron. Sustain. Dev. 2008, 28, 489-495. [CrossRef]

58. Libutti, A.; Monteleone, M. Soil vs. groundwater: The quality dilemma. Managing nitrogen leaching and salinity control under irrigated agriculture in Mediterranean conditions. Agric. Water Manag. 2017, 186, 40-50. [CrossRef]

59. Yuan, X.M.; Tong, Y.A.; Yang, X.Y.; Li, X.L.; Zhang, F.S. Effect of organic manure on soil nitrate nitrogen accumulation. Soil Environ. Sci. 2000, 9, 197-200. [CrossRef]

60. González-Delgado, A.M.; Shukla, M.K. Transport of Nitrate and Chloride in Variably Saturated Porous Media. J. Irrig. Drain. Eng. 2014, 140, 04014006. [CrossRef]

61. Lao, M.T. Gestión del Fertirriego de los Invernaderos de Almería Mediante el Uso de Sondas de Succión. Ph.D. Thesis, Universidad Almería, Almería, Spain, 2002.

62. Hopkins, B.; Ellsworh, J. Phosphorus Availability with Alkaline/Calcareous Soil. In Proceedings of the Western Nutrient Management Conference, Reno, NV, USA, 5-6 March 2005; pp. 88-93.

63. Jadczuk, E.; Zmudzin, J. Lixiviation of $\mathrm{K}$ and $\mathrm{Mg}$ out of an alluvial silty loam soil under conditions of increased or restricted water supply. Acta Hortic. 1990, 274, 207-214. [CrossRef]

64. Corley, R.H.V.; Tinker, P.B.H. The Oil Palm (World Agriculture Series), 4th ed.; Wiley-Blackwell: Oxford, UK, 2003; p. 592. ISBN 978-0-632-05212-7.

65. Griffioen, J. Potassium adsorption ratios as an indicator for the fate of agricultural potassium in groundwater. J. Hydrol. 2001, 254, 244-254. [CrossRef] 